\title{
Response of Microcystis aeruginosa BCCUSP 232 to barley (Hordeum vulgare L.) straw degradation extract and fractions
}

\author{
Gustavo Franciscatti Mecina a,b, Anne Lígia Dokkedal ${ }^{\mathrm{c}}$, Luiz Leonardo Saldanha ${ }^{\mathrm{c}}$, Mathias Ahii Chia ${ }^{\mathrm{d}, \mathrm{e}}$, \\ Micheline Kézia Cordeiro-Araújo ${ }^{\mathrm{e}}$, \\ Maria do Carmo Bittencourt-Oliveira ${ }^{\mathrm{e}}$, Regildo Márcio Gonçalves da Silva ${ }^{\mathrm{a}, \mathrm{b}, *}$
}

a Universidade Estadual Paulista (UNESP), Laboratório de Fitoterápicos, Departamento de Biotecnologia, Faculdade de Ciências e Letras de Assis, Avenida Dom Antônio 2100, CEP: 19806-900 Assis, São Paulo, Brazil

${ }^{\mathrm{b}}$ Universidade Estadual Paulista (UNESP), Instituto de Química de Araraquara, Rua Prof. Francisco Degni 55, CEP: 14800-060 Araraquara, São Paulo, Brazil

' Universidade Estadual Paulista (UNESP), Instituto de Biociências de Botucatu, Departamento de Botânica, Fisiologia Vegetal, Distrito de Rubião Jr., s/n, CEP: 18618-970, Botucatu, São Paulo, Brazil

d Departamento de Ciências Biológicas, Escola Superior de Agricultura Luiz de Queiroz, Universidade de São Paulo, Piracicaba, SP, Brazil

e Department of Botany, Ahmadu Bello University, Zaria Postal Code 810001, Nigeria

\section{H I G H L I G H T S}

- H. vulgare extract significantly reduced the cell density in a concentration dependent manner.

- The extract had an immediate inhibitory effect on the biomass of the cyanobacterium.

- Internal $\mathrm{H}_{2} \mathrm{O}_{2}$ concentration increased after exposure to the crude extract.

- Changes in POD, SOD and GST activities of $M$. aeruginosa exposed to $H$. vulgare crude extract.

- Reactive oxygen species, lipid peroxidation and antioxidant enzyme activities were altered.

\section{A R T I C L E I N F O}

\section{Article history:}

Received 27 March 2017

Received in revised form 16 May 2017

Accepted 17 May 2017

Available online 20 May 2017

Editor: D. Barcelo

\section{Keywords:}

Cyanobacteria

Eutrophication

Polyphenols

Antioxidant enzyme

Microcystins

\section{G R A P H I C A L A B S T R A C T}

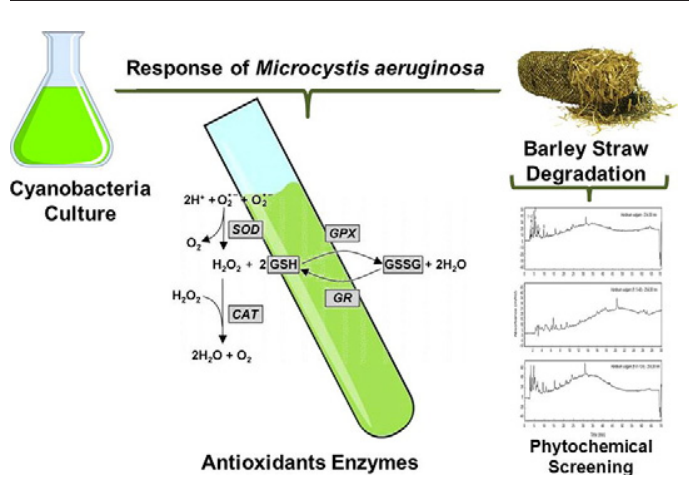

\begin{abstract}
A B S T R A C T
The eutrophication of aquatic ecosystems is a serious environmental problem that leads to increased frequency of cyanobacterial blooms and concentrations of cyanotoxins. These changes in aquatic chemistry can negatively affect animal and human health. Environment-friendly methods are needed to control bloom forming cyanobacteria. We investigated the effect of Hordeum vulgare L. (barley) straw degradation extract and its fractions on the growth, oxidative stress, antioxidant enzyme activities, and microcystins content of Microcystis aeruginosa (Kützing) Kützing BCCUSP232. Exposure to the extract significantly $(p<0.05)$ inhibited the growth of $M$. aeruginosa throughout the study, whereas only the highest concentration of fractions 1 and 2 significantly $(p<0.05)$ reduced the growth of the cyanobacterium on day 10 of the experiment. The production of reactive oxygen species (ROS), lipid peroxidation and antioxidant enzyme activities were significantly $(p<0.05)$ altered by the extract and fractions 1 and 2. Phytochemical profiling of the extract and its fractions revealed that the barley straw degradation process yielded predominantly phenolic acids. These results demonstrate that barley straw
\end{abstract}

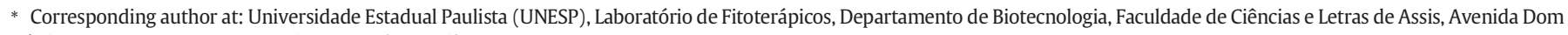
Antônio 2100, CEP: 19806-900, Assis, São Paulo, Brazil.

E-mail address: regildo@assis.unesp.br (R.M.G. da Silva). 
extract and its fractions can efficiently interfere with the growth and development of $M$. aeruginosa under laboratory conditions.

\section{Introduction}

The eutrophication of water resources is a serious environmental problem that is driven by nutrient loading from industrial and urban wastewater, and leaching of agricultural inputs (Heisler et al., 2008). Consequent upon the eutrophication of aquatic ecosystems, the frequency of cyanobacterial blooms and the concentration of cyanotoxins are increased. This interferes with the management of water resources, and deteriorates water quality (Barrett et al., 1996; Ferrier et al., 2005). Cyanotoxins include potent neurotoxins, hepatotoxins, cytotoxins and endotoxins that have been implicated in animal and human deaths (Sivonen and Jones, 1999; Gugger et al., 2005; Rodriguez et al., 2007; Pearson et al., 2010), and their accumulation in plant and animal tissues has led to their detection in human diet (Gangstad, 1986; Vymazal, 1995; El-Shehawy et al., 2012). As a result of the risk associated with cyanotoxins exposure, the World Health Organization (WHO) recommended $1 \mu \mathrm{g} \mathrm{L}^{-1}$ as the maximum permissible level of microcystin-LR in drinking water (WHO, 2004).

Biological, chemical and physical methods have been employed for the control of the harmful algae and their associated problems. Physical methods comprise filtration, centrifugal separation and ultrasound treatments (Chorus and Bartram, 1999; Kotopoulis et al., 2009; Liang and Nan, 2009); chemical methods employ compounds such as copper sulfate and hydrogen peroxide (Drabkova et al., 2007); and biological methods use selected fish and zooplankton species to control the population of harmful algae and cyanobacteria (Chorus and Bartram, 1999; Chen et al., 2007). Most of these methods have not been very successful, are very expensive and are primarily used as emergency solutions. There is the need to develop efficient, sustainable and cost effective techniques with little or no environmental footprints (Ferrier et al., 2005). As an alternative, compounds of plant origin can be employed in controlling microorganisms (e.g. microalgae and cyanobacteria)
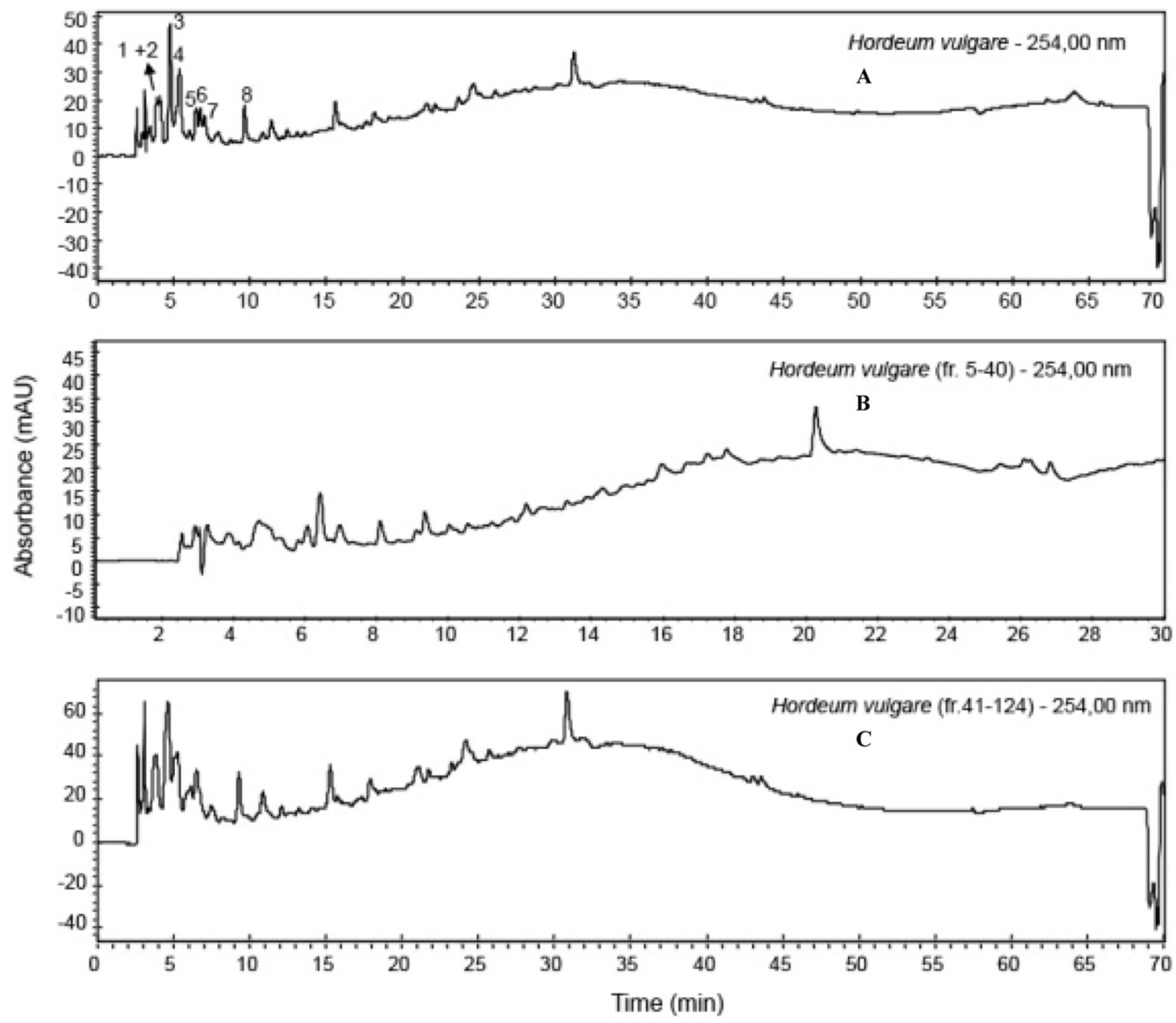

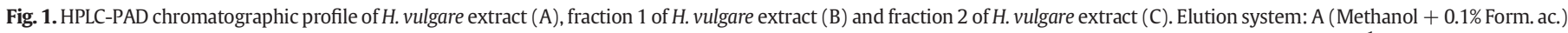

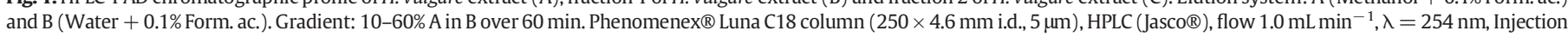
volume: $20 \mu \mathrm{L}$. Column oven: $40{ }^{\circ} \mathrm{C}$. 
that threaten public and environmental health, and agricultural production (Smith and Doan, 1999; Gibson et al., 1990; Pillinger et al., 1992; Park et al., 2006; Leflaive and Ten-Hage, 2007; Zak et al., 2011; Bártová et al., 2011; Hajimahmoodi et al., 2010). This encourages the search for bioactive compounds from different plants. Barley (Hordeum vulgare L.) is a promising source of bioactive compounds, and has been previously shown to inhibit the growth of freshwater algae and cyanobacteria (Ferrier et al., 2005; Ó Huallacháin and Fenton, 2008, 2010; Rajabi et al., 2010). The degradation products of barley straw contain polyphenols and quinones that have been implicated in the inhibition of algal and cyanobacterial species (Pillinger et al., 1992; Everall and Lees, 1997; Martin and Ridge, 1999; Waybright et al., 2009).

Although it has been previously shown that barley straw extract is capable of inhibiting the growth of cyanobacteria, the mechanism of action was not defined. Changes in growth, oxidative stress and antioxidant response provide new insights into the physiological changes toxin producing cyanobacteria undergo during exposure to barley straw extracts. Furthermore, previous studies did not considered changes in toxin production of cyanobacteria as a function of the presence and concentrations of barley extract and fractions.

So the objective of the present study was to investigate changes in growth, toxin content, oxidative stress and antioxidant response of $M$. aeruginosa during exposure to barley straw degradation extract and fractions. Beyond the conventional growth inhibition tests, the results obtained from the present study will contribute to the understanding of the mechanism of action of the degradation products of barley straw on the cyanobacterium Microcystis.

\section{Material and methods}

\subsection{Plant material and extract preparation}

Hordeum vulgare L. straw was obtained from an Agricultural plantation of the Instituto Agronômico de Campinas, São Paulo, Brazil. The straw was cut into $2.0 \mathrm{~cm}$ pieces, weighed and extracted by degradation in distilled water $\left(2 \mathrm{~g} \mathrm{~L}^{-1}\right)$. The decomposition process was carried out in polyethylene screw capped containers, which were aerated with an air pump for 50 days at room temperature. Afterwards, the extract was filtered, frozen and lyophilized following the procedures outlined by Ferrier et al. (2005).

In order to fractionate barley straw extract, $2.0 \mathrm{~g}$ of lyophilized extract was dissolved in $12 \mathrm{~mL} \mathrm{MeOH}: \mathrm{H}_{2} \mathrm{O}(60: 40, \mathrm{v} / \mathrm{v})$, sonicated for $10 \mathrm{~min}$, and the solution centrifuged for $15 \mathrm{~min}(1200 \times \mathrm{g})$. The supernatant was filtered and chromatographed using gel permeation chromatography (GPC) on Sephadex® LH-20 column. The samples were eluted with $\mathrm{MeOH}: \mathrm{H}_{2} \mathrm{O}(60: 40, v / v)$. Every $15 \mathrm{~min}$, fractions of approximately $15 \mathrm{~mL}$ were collected.

The GPC separation of $H$. vulgare gave 60 fractions that were screened by TLC and grouped according to their similarities ( $\mathrm{Rf}$ and color) into sub-fractions. Thus it was possible to verify that the
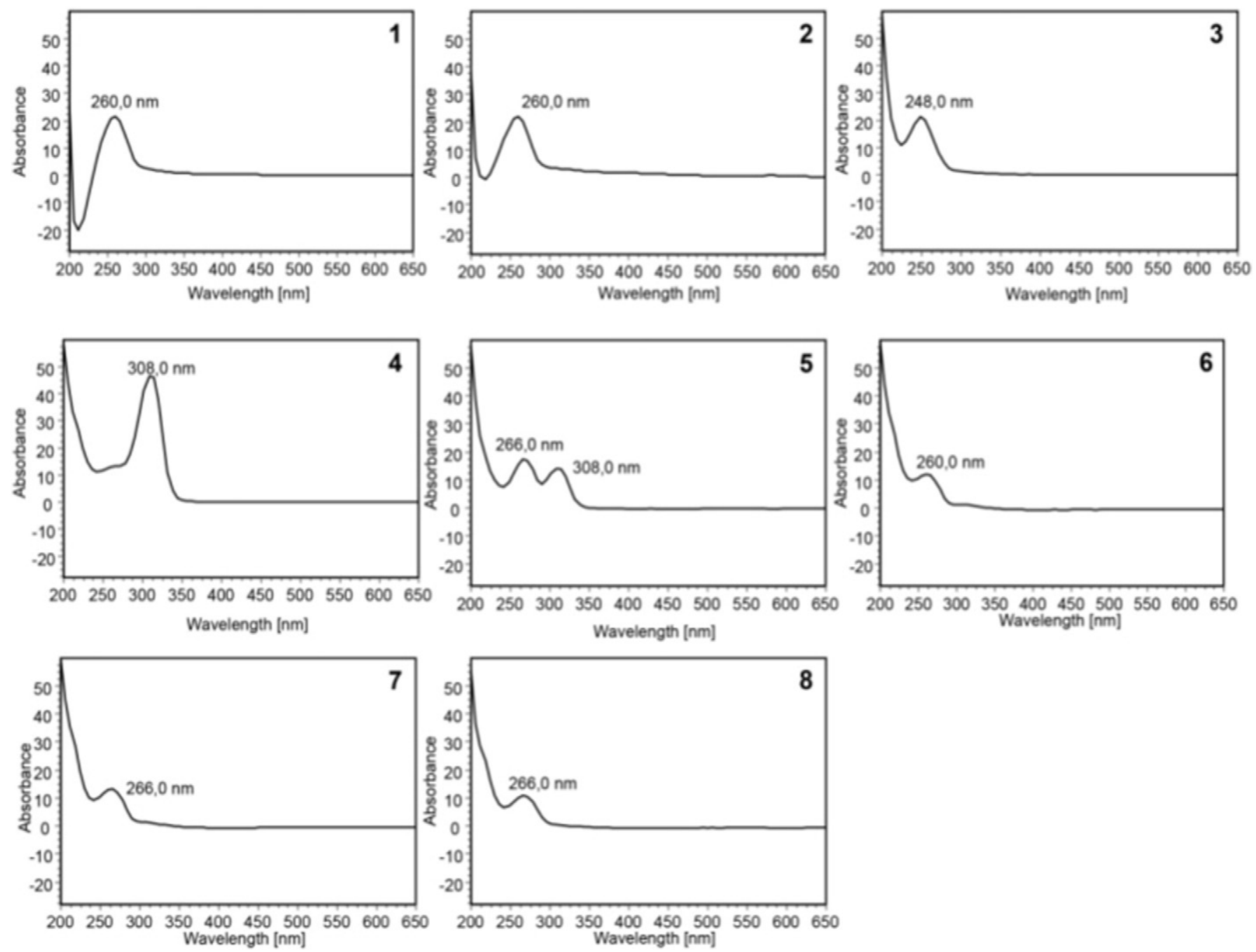

Fig. 2. (A) Maximum absorption bands in the UV region for phenolic acids found in the Hordeum vulgare straw extract. 


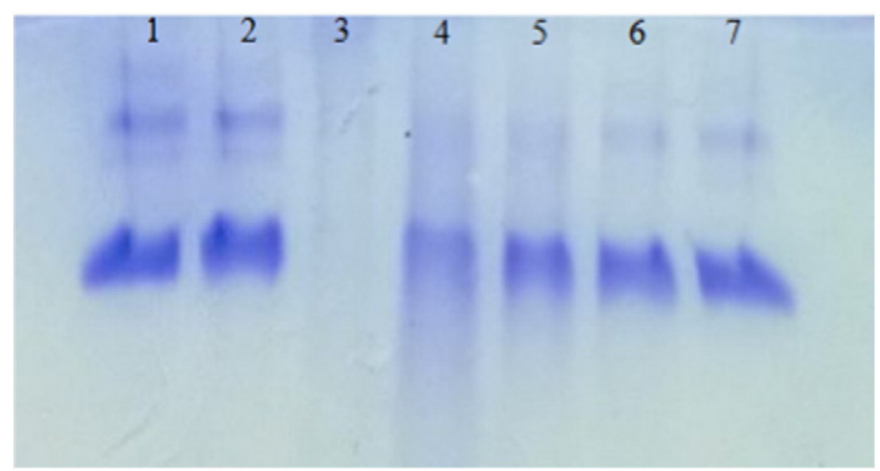

Fig. 3. Coomassie Brilliant Blue stained polyacrylamide gel showing oxidative degradation of albumin. 1) BSA (negative control); 2) $\mathrm{BSA}+\mathrm{Cu} ; 3$ ) $\mathrm{BSA}+\mathrm{Cu}+\mathrm{H}_{2} \mathrm{O}_{2}$ (Positive control); 4) BSA + $\mathrm{Cu}+500 \mu \mathrm{g} \mathrm{mL} \mathrm{L}^{-1}$ extract; 5) $\mathrm{BSA}+\mathrm{Cu}+250 \mu \mathrm{g} \mathrm{mL}{ }^{-1}$ extract; 6) $\mathrm{BSA}+\mathrm{Cu}+100 \mu \mathrm{g} \mathrm{mL}{ }^{-1}$ extract; 7) $\mathrm{BSA}+\mathrm{Cu}+10 \mu \mathrm{g} \mathrm{mL}{ }^{-1}$ extract.

preliminary separation by GPC concentrated more polar compounds in fractions collected at the beginning of the separation process, while later fractions comprised phenolic acid derivatives and flavonoid compounds, which were reassembled into two fractions (fraction 1 and fraction 2). Once reassembled, the sub fractions were dried until complete removal of solvents.

\subsection{Phytochemical screening of $H$. vulgare extract}

Using gallic acid as a standard, the Folin-Ciocalteu method was used to measure total phenol content of the extracts (Stagos et al., 2012). To each $0.1 \mathrm{~mL}\left(1000 \mu \mathrm{g} \mathrm{mL}{ }^{-1}\right)$ aliquot of the extract, $5 \mathrm{~mL}$ distilled water and $0.5 \mathrm{~mL}$ Folin-Ciocalteu reagent were added. After $3 \mathrm{~min}, 1.4 \mathrm{~mL} \mathrm{25 \%}$ $\mathrm{Na}_{2} \mathrm{CO}_{3}$ and $3 \mathrm{~mL}$ distilled water were added, and the mixture incubated for $1 \mathrm{~h}$. Subsequently, the absorbance of the mixture was measured at $725 \mathrm{~nm}$. All measurements were performed in triplicate and the results expressed in $\mu$ g gallic acid/mg extract.

Total flavonoid concentration was measured using the complexation of flavonoids with $\mathrm{AlCl}_{3}$, a process that changes absorption bands to higher wavelengths (Yao et al., 2013). One milliliter extract aliquot $\left(1000 \mu \mathrm{g} \mathrm{mL}^{-1}\right)$ was mixed with $4 \mathrm{~mL} 70 \%$ ethanol and $0.5 \mathrm{~mL} \mathrm{NaNO}_{2}$ to give a $5 \%$ solution. After 6 min of incubation, $0.5 \mathrm{~mL} 10 \% \mathrm{AlCl}_{3}$ solution and $3 \mathrm{~mL} 1 \mathrm{M} \mathrm{NaOH}$ solution were added to the mixture, and then the total volume brought to $10 \mathrm{~mL}$ with distilled water. The mixture was vortexed, and the absorbance read at $510 \mathrm{~nm}$. All assays were carried out in triplicate, and the flavonoid concentrations given in $\mu \mathrm{g}$ rutin $/ \mathrm{mg}$ extract.

Prior to high performance liquid chromatography (HPLC) analysis, $10 \mathrm{mg}$ aliquot of barley straw extract was dissolved in $1 \mathrm{~mL}$ methanol/ water (1:1) and filtered through a $0.45 \mu \mathrm{m}$ pore size SPE syringe filter. Chromatographic analysis was performed with a Jasco® Model PU2089S Plus HPLC system coupled to a MD-2015 photodiode array detector (scan range 200-900 nm), an AS-2055 auto sampler with $50 \mathrm{~mL}$ loop, and a CO-2060 column oven (Jasco®, Hachioji, Tokyo, Japan).
Reverse phase immobilized $250 \times 4.6 \mathrm{~mm}$ idoctadecylsilane column (Phenomenex Inc., Torrance, CA, USA) and $4 \times 3 \mathrm{~mm}$ id guard column were used (Phenomenex Inc., Torrance, CA, USA). Mobile phase comprised methanol $+0.1 \%$ Formic acid $(A)$, and Water $+0.1 \%$ Formic acid (B). Gradient was $05-100 \%$ of A in B for 60 min. Chromatograms were obtained at 254, 330 and $360 \mathrm{~nm}$. The Jasco ChromPass v.1.8.1.6 software was used for acquisition and processing of chromatographic data.

\subsection{Evaluation of pro-oxidative activity of $\mathrm{H}$. vulgare extract}

\subsubsection{Sample preparation}

Relative mobility of electrophoresis was measured according to the method of Hsieh et al. (2005). Bovine serum albumin (BSA, $2 \mathrm{mg} \mathrm{mL}^{-1}$ ) was diluted in $10 \mathrm{mM}$ phosphate buffer ( $\mathrm{pH} 7.4$ ). The $\mathrm{H}_{2} \mathrm{O}_{2} / \mathrm{CuSO}_{4}$ oxidation system consisted of $50 \mathrm{mM} \mathrm{H} \mathrm{H}_{2} \mathrm{O}_{2}$ and $1 \mathrm{mg} \mathrm{mL}^{-1}$ CuSO4 solution (Hunt et al., 1988). The negative control of the tests contained $1 \mathrm{~mL}$ of BSA solution and $1 \mathrm{~mL}$ phosphate buffer; positive control had $1 \mathrm{~mL}$ of $\mathrm{BSA}, 0.5 \mathrm{~mL} \mathrm{H}_{2} \mathrm{O}_{2} / \mathrm{CuSO}_{4}$ solution and $0.5 \mathrm{~mL}$ phosphate buffer; and the treatment contained $1 \mathrm{~mL} \mathrm{BSA}$, $0.5 \mathrm{~mL} \mathrm{H}_{2} \mathrm{O}_{2} / \mathrm{CuSO}_{4}$ solution and $0.5 \mathrm{~mL}$ of $\mathrm{H}$. vulgare extract at 10 , 100,250 and $500 \mu \mathrm{gL} \mathrm{m}^{-1}$. The negative control, positive control, and treatments were incubated at $37^{\circ} \mathrm{C}$ for $48 \mathrm{~h}$. BSA electrophoresis was performed using polyacrylamide gel electrophoresis (SDS-PAGE).

\subsubsection{One-dimensional gel electrophoresis (SDS-PAGE) preparation}

The pro-oxidative activity of different concentrations of $H$. vulgare extract was analyzed using one-dimensional electrophoresis in polyacrylamide gel (Laemmli, 1970; Kocha et al., 1997). The 12\% polyacrylamide gels (22.2\% acrylamide/0.6-bis acrylamide; $1 \mathrm{M}$ Tris- $\mathrm{HCl}$, pH 8.8; distilled water; $10 \%$ SDS; $10 \%$ ammonium persulfate, TEMED) were mounted on K33-10 V electrophoresis system $10 \times 10 \mathrm{~cm}$ plates (Kasvi, Brazil). The negative control, positive control and treatment samples were incubated in a sample buffer ( $1 \mathrm{M}$ Tris- $\mathrm{HCl}, \mathrm{pH} 6.8,4 \%$ SDS, 20\% Glycerol, 5\% B-mercaptoethanol, 0.2\% bromophenol blue) at $95{ }^{\circ} \mathrm{C}$ for $5 \mathrm{~min}$, and then applied to sodium dodecyl sulfate polyacrylamide gel. The BSA protein was electrophoretically separated at $200 \mathrm{~mA}$ and $100 \mathrm{~V}$. After the run, the gels were stained with Coomassie solution (Coomassie Bright Blue R-250 in 50\% methanol and 10\% acetic acid) and stored in $7 \%$ acetic acid until image scanning. In addition, for better visualization of the electrophoretic profile of some samples, staining was done with silver nitrate.

\subsection{Bioassays with Microcystis aeruginosa BCCUSP232}

For the assays, Microcystis aeruginosa BCCUSP232 was obtained from the Brazilian Cyanobacteria Collection of the University of Sao Paulo. The cyanobacterium produces microcistin-LR and RR (BittencourtOliveira et al., 2011). The cultures were maintained in ASM-1 culture medium at pH 7.4 (Gorham et al., 1964) under controlled conditions (30 $\mu \mathrm{mol} \mathrm{m} \mathrm{m}^{-2} \mathrm{~s}^{-1}$ light intensity, 14:10 h light:dark cycle photoperiod, and $23 \pm 0.5{ }^{\circ} \mathrm{C}$ temperature).

All bioassays were carried out in $1000 \mathrm{~mL}$ Erlenmeyer flasks containing $600 \mathrm{~mL}$ of culture medium. For each treatment, $2.3 \times 10^{5}{\mathrm{cells} \mathrm{mL}^{-1}}^{-1}$

Table 1

Growth of M. aeruginosa BCCUSP232 exposed to different Hordeum vulgare L. straw extract concentrations (50, 100, 250 and 500 mg $\left.\mathrm{L}^{-1}\right)$.

\begin{tabular}{|c|c|c|c|c|c|}
\hline \multicolumn{6}{|c|}{ Cell density $\left(\times 10^{3}\right.$ cells $\left.\mathrm{mL}^{-1}\right)$} \\
\hline & Concentrations & 4th day & 6 th day & 8th day & 10th day \\
\hline \multirow{4}{*}{ H. vulgare extract } & $50 \mathrm{mg} \mathrm{L}^{-1}$ & $595 \pm 84 a$ & $1.284 \pm 171 \mathrm{a}$ & $1.662 \pm 201 a$ & $3.073 \pm 491 \mathrm{a}$ \\
\hline & $100 \mathrm{mg} \mathrm{L}^{-1}$ & $340 \pm 58 a$ & $651 \pm 183 b$ & $762 \pm 283 b$ & $1.684 \pm 517 b$ \\
\hline & $250 \mathrm{mg} \mathrm{L}^{-1}$ & $418 \pm 102 a$ & $962 \pm 217 b$ & $273 \pm 000 c$ & $817 \pm 483 c$ \\
\hline & $500 \mathrm{mg} \mathrm{L}^{-1}$ & $307 \pm 115 a$ & $918 \pm 359 b$ & $000 \pm 000 d$ & $000 \pm 000 d$ \\
\hline Control & & $495 \pm 102 a$ & $1.129 \pm 157 a$ & $1.718 \pm 164 a$ & $2.595 \pm 189 a$ \\
\hline
\end{tabular}

Results are means \pm standard deviation for $n=3$. Means with different alphabets per column are significantly different $(p<0.05)$. 
Table 2

Growth of M. aeruginosa BCCUSP232 as a function of different concentrations (25, 50 and $100 \mathrm{mg} \mathrm{L}^{-1}$ ) of fraction 1 obtained from Hordeum vulgare L. straw extract.

\begin{tabular}{llllll}
\hline \multicolumn{2}{c}{ Cell density $\left(\times 10^{3}{\left.\text { cells } \mathrm{mL}^{-1}\right)}\right.$} & & & \\
\hline & Concentrations & 4 th day & 6 th day & 8 th day & 10 th day \\
& $25 \mathrm{mg} \mathrm{L}^{-1}$ & 623 & 957 & 1.590 & 2.473 \\
Fraction & & $\pm 24 \mathrm{a}$ & $\pm 71 \mathrm{a}$ & $\pm 165 \mathrm{a}$ & $\pm 141 \mathrm{a}$ \\
1 & $50 \mathrm{mg} \mathrm{L}^{-1}$ & 657 & $907 \pm 0 \mathrm{~b}$ & $1.473 \pm 47 \mathrm{a}$ & $2.373 \pm 0 \mathrm{~b}$ \\
& & $\pm 24 \mathrm{a}$ & & & \\
& \multirow{2}{*}{$100 \mathrm{mg} \mathrm{L}^{-1}$} & 607 & 873 & 1.307 & 2.057 \\
& & $\pm 47 \mathrm{a}$ & $\pm 94 \mathrm{~b}$ & $\pm 188 \mathrm{c}$ & $\pm 306 \mathrm{c}$ \\
Control & & 573 & $951 \pm 0 \mathrm{a}$ & $1.557 \pm 47 \mathrm{a}$ & $2.462 \pm 23 \mathrm{a}$ \\
& & $\pm 24 \mathrm{a}$ & & & \\
\hline
\end{tabular}

were used as the initial cell density (day 0). After $96 \mathrm{~h}$ at exponential growth phase, $M$. aeruginosa was exposed to different concentrations $\left(50,100,250\right.$ and $\left.500 \mathrm{mg} \mathrm{L}^{-1}\right)$ of Hordeum vulgare extract. The negative control contained only water. In a second series of experiments, exponential growth phase $M$. aeruginosa was exposed to the different fractions obtained in section 2.2 above. For each fraction, the cyanobacterium was exposed to 25,50 and $100 \mathrm{mg} \mathrm{L}^{-1}$ concentration. During exposure to each extract and fraction treatment, the cyanobacterium was incubated for 10 days under the same conditions as the stock cultures described above. All experimental treatments were carried in triplicates.

Sample aliquots were collected every two days for growth and biomass determination. Cell density was determined using a combination of optical density at $750 \mathrm{~nm}\left(\mathrm{y}=3 \mathrm{E}-08 \times+0.0058, \mathrm{R}^{2}=0.9992\right)$, and microscopic counts with the aid of a Fuchs Rosenthal counting chamber.

\subsection{Biochemical analyses}

For biochemical analyses, $M$. aeruginosa biomass was obtained from $40 \mathrm{~mL}$ of culture by centrifugation at $1200 \times \mathrm{g}$ for $5 \mathrm{~min}$, and the resulting pellet (biomass) stored at $-80^{\circ} \mathrm{C}$. The pellet was resuspended in $2 \mathrm{~mL} 0.1 \mathrm{M}$ phosphate buffer ( $\mathrm{pH} 6.5$ ) containing $1 \%(\mathrm{w} / \mathrm{v}$ ) polyvinylpyrrolidone (PVP). The mixture was homogenized by vortexing for $10 \mathrm{~s}$, centrifuged $\left(10,000 \times \mathrm{g}, 0{ }^{\circ} \mathrm{C}, 10 \mathrm{~min}\right)$ and the supernatant stored at $-20{ }^{\circ} \mathrm{C}$ for biochemical assays.

Internal $\mathrm{H}_{2} \mathrm{O}_{2}$ levels in $M$. aeruginosa were determined by monitoring the formation of titanium peroxide (Jana and Choudhuri, 1982). A $750 \mu \mathrm{L}$ aliquot of the extract was mixed with $250 \mu \mathrm{L}$ of $0.1 \%$ titanium chloride (in $20 \% \mathrm{H}_{2} \mathrm{SO}_{4}$ ). Absorbance of the redorange solution was measured at $410 \mathrm{~nm} . \mathrm{H}_{2} \mathrm{O}_{2}$ concentration was calculated using its extinction coefficient $\left(0.28 \mathrm{~L} \mathrm{mmol}^{-1} \mathrm{~cm}^{-1}\right)$ and expressed as $\mu \mathrm{mol} / \mathrm{cell}$.

The formation of Malondialdehyde (MDA) was measured using the thiobarbituric acid (TBA) method (Madhava Rao and Sresty, 2000) with some modifications. To $1 \mathrm{~mL}$ aliquot of the extracts was added $4 \mathrm{~mL} 0.5 \%(\mathrm{w} / \mathrm{v})$ TBA in 20\% TCA (w/v), and the reaction mixture incubated at $95^{\circ} \mathrm{C}$ for $30 \mathrm{~min}$ in a water bath. The reaction was immediately stopped by cooling in an ice bath, and the mixture centrifuged at $10000 \mathrm{~g}$ for $15 \mathrm{~min}$ and vortexed. The absorbance of the mixture was read at $532 \mathrm{~nm}$ and corrected at $600 \mathrm{~nm}$. MDA concentration $(\mathrm{mM})$
A
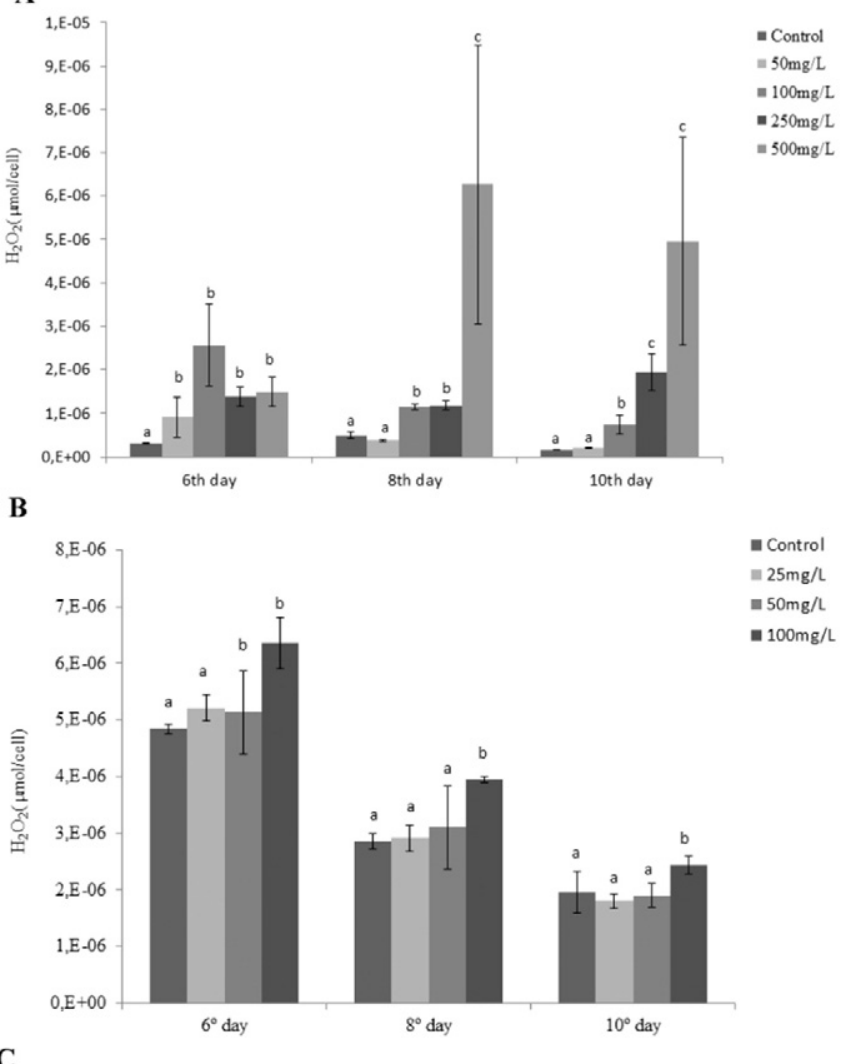

C

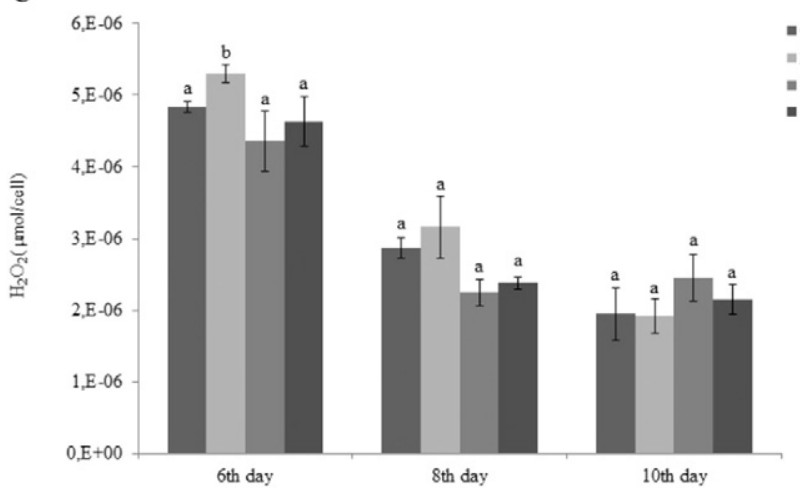

Fig. 4. Intracellular $\mathrm{H}_{2} \mathrm{O}_{2}$ content of $M$. aeruginosa BCCUSP232 exposed to different concentrations of $H$. vulgare extract (A), fraction 1 of $H$. vulgare extract (B), and fraction 2 of $H$. vulgare extract (C). Error bars represent standard deviation for $n=3$. Means with different alphabets are significantly different $(p<0.05)$.

was calculated using the extinction coefficient of $155 \mathrm{mM}^{-1} \mathrm{~cm}^{-1}$ (Demiral and Türkan, 2005):

$[M D A](m M)=\frac{\text { Abs 532-Abs } 600}{155,10}$

In order to determine specific activity of antioxidant enzymes, total protein content was quantified. Using BSA as protein standard, total

Table 3

Growth of M. aeruginosa BCCUSP232 as a function of different concentrations ( 25,50 and $\left.100 \mathrm{mg} \mathrm{L}^{-1}\right)$ of fraction 2 obtained from Hordeum vulgare L. straw extract.

\begin{tabular}{|c|c|c|c|c|c|}
\hline \multicolumn{6}{|c|}{ Cell density $\left(\times 10^{3}\right.$ cells $\left.\mathrm{mL}^{-1}\right)$} \\
\hline \multirow{4}{*}{ Fraction 2} & Concentrations & 4th day & 6th day & 8th day & 10th day \\
\hline & $25 \mathrm{mg} \mathrm{L}^{-1}$ & $590 \pm 23 a$ & $973 \pm 0 \mathrm{ab}$ & $1.507 \pm 141 \mathrm{a}$ & $2.307 \pm 47 b$ \\
\hline & $50 \mathrm{mg} \mathrm{L}^{-1}$ & $607 \pm 47 a$ & $1.040 \pm 94 \mathrm{ab}$ & $1.590 \pm 23 a$ & $2.273 \pm 94 b$ \\
\hline & $100 \mathrm{mg} \mathrm{L}^{-1}$ & $573 \pm 38 a$ & $1107 \pm 47 b$ & $1.623 \pm 23 a$ & $2.207 \pm 94 b$ \\
\hline Control & & $573 \pm 24 a$ & $951 \pm 0 \mathrm{a}$ & $1.557 \pm 47 a$ & $2.462 \pm 23 a$ \\
\hline
\end{tabular}


A

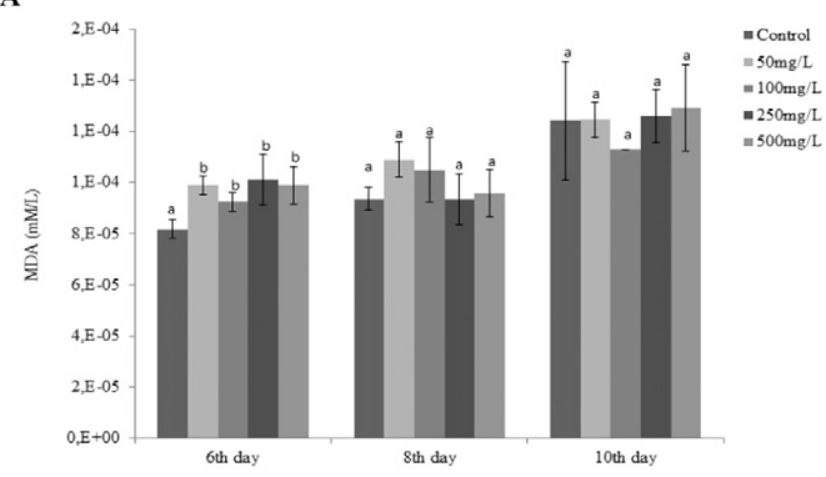

B

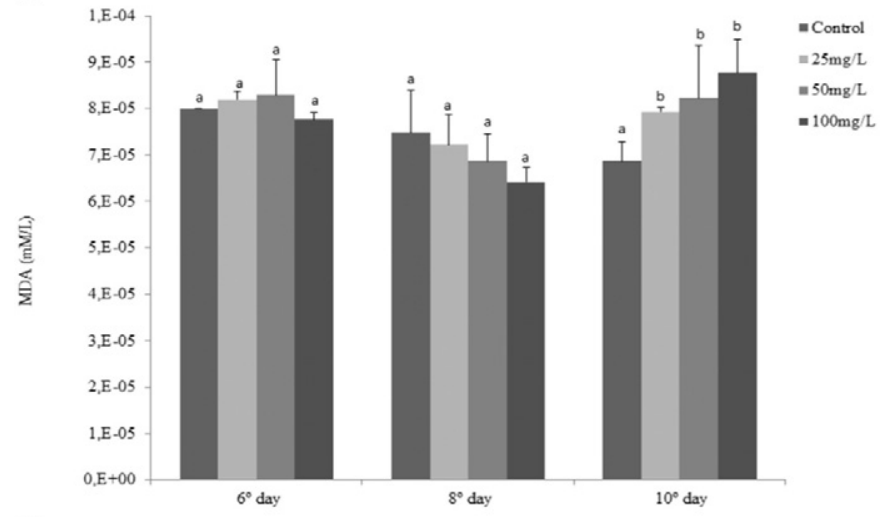

C

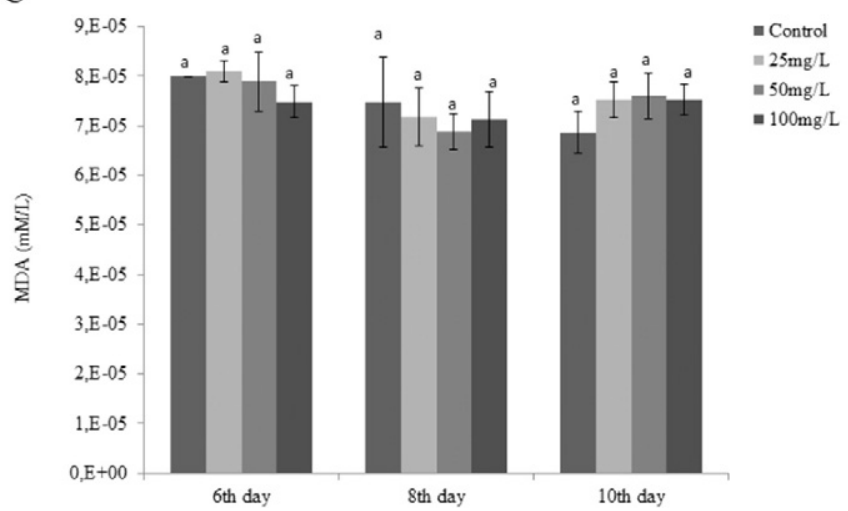

Fig. 5. Lipid peroxidation in M. aeruginosa BCCUSP232 exposed to different concentrations of $H$. vulgare extract (A), fraction 1 of $H$. vulgare extract (B), and fraction $2 \mathrm{of} H$. vulgare extract $(C)$. Error bars represent standard deviation for $n=3$. Means with different alphabets are significantly different $(p<0.05)$.

protein concentration was measured following the procedure described by Bradford (1976). Superoxide dismutase activity was determined spectrophotometrically according to Misra and Fridovich (1972). Keeping SOD concentration below 1 unit (U), the $3 \mathrm{~mL}$ reaction mixture used to measure the activity of the enzyme contained $6.7 \mathrm{mM}$ potassium phosphate buffer ( $\mathrm{pH} 7.8$ ), $45 \mu \mathrm{M}$ methionine, $5.3 \mathrm{mM}$ riboflavin and $84 \mu \mathrm{M}$ nitro blue tetrazolium chloride (NBT). One enzymatic unit was defined as the amount of enzyme required to inhibit 50\% NBT reduction. Peroxidase activity was assayed following the method of Reddy et al. (1995). To $3 \mathrm{~mL}$ of $0.05 \mathrm{M}$ pyrogallol solution in $0.1 \mathrm{M}$ phosphate buffer ( $\mathrm{pH} 6.5$ ), $0.5 \mathrm{~mL} 1 \% \mathrm{H}_{2} \mathrm{O}_{2}$ was added and gently mixed, and the reaction initiated by the addition of $0.1 \mathrm{~mL}$ enzyme extract. The activity (nkat $\mathrm{mg}^{-1}$ protein) of the enzyme was proportional to the change in absorbance per minute.

Glutathione S-transferase activity was measured at $340 \mathrm{~nm}$ using 1chloro-2,4-dinitrobenzene (CDNB) and reduced glutathione (GSH) as substrates (Mauch and Dudler, 1993). Enzymatic reaction was started by the addition of $50 \mu \mathrm{L}$ enzyme extract to $1 \mathrm{~mL}$ of reaction mixture (3.6 $\mathrm{mM} \mathrm{GSH}$ and $1 \mathrm{mM}$ CDNB in $0.1 \mathrm{M}$ potassium phosphate buffer, $\mathrm{pH}$ 6.5). The change in absorbance at $340 \mathrm{~nm}$ was proportional to GST activity (nkat $\mathrm{mg}^{-1}$ protein). Catalase (CAT) activity of the cyanobacterium was assayed using its perioxidatic function (Johansson and Borg, 1988). Methanol was used as the hydrogen donor for CAT, which results in the formation of formaldehyde. Subsequently, the formaldehyde was measured colorimetrically with Purpald, and a unit (U) of CAT activity was equivalent to the amount of enzyme that caused the formation of $200 \mu \mathrm{M}$ formaldehyde. CAT activity was expressed in nkat $\mathrm{mg}^{-1}$ protein.

\subsection{Microcystins analysis}

Microcystins extraction was performed on frozen culture samples in $1.5 \mathrm{~mL}$ microcentrifuge tubes. The samples were thawed at room temperature, and rapidly subjected to 3 freeze (in liquid nitrogen for $30 \mathrm{~s}$ ) - thaw (in a water bath at $37{ }^{\circ} \mathrm{C}$ for $5 \mathrm{~min}$ ) cycles. Total microcystins concentration was measured using BEACON ELISA plate kits (Beacon Analytical Systems Inc., USA), following the manufacturer's instructions. The absorbance of the color reaction was measured at $450 \mathrm{~nm}$ with an

A

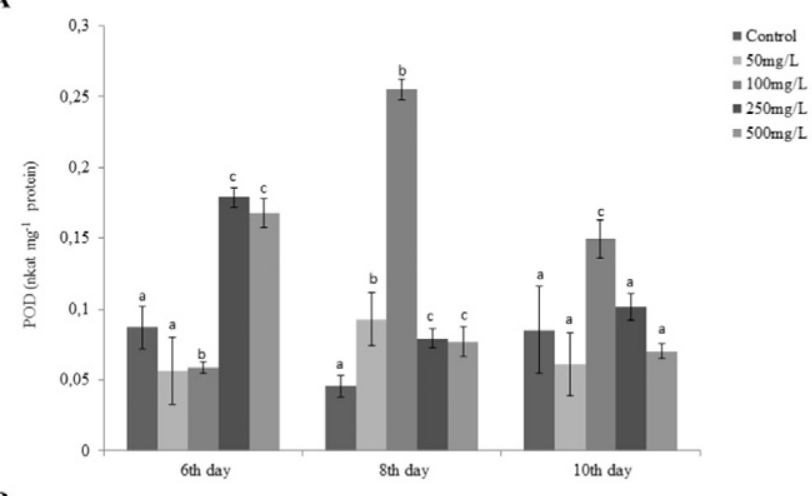

B

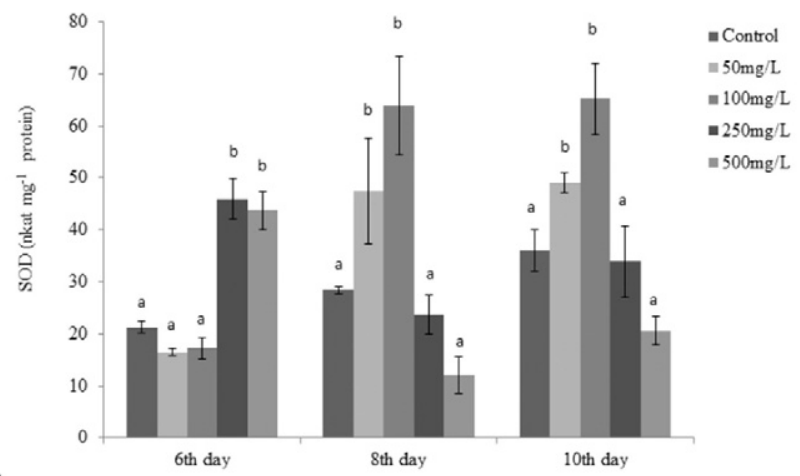

C

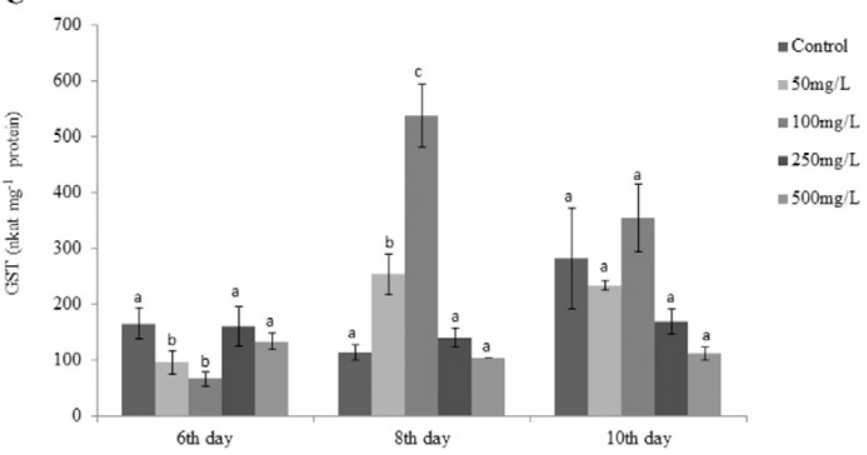

Fig. 6. Effect of different concentrations of $H$. vulgare extract on POD (A), SOD (B) and GST (C) activities of M. aeruginosa BCCUSP232. Error bars represent standard deviation for $n=$ 3. Means with different alphabets are significantly different $(p<0.05)$. 
A

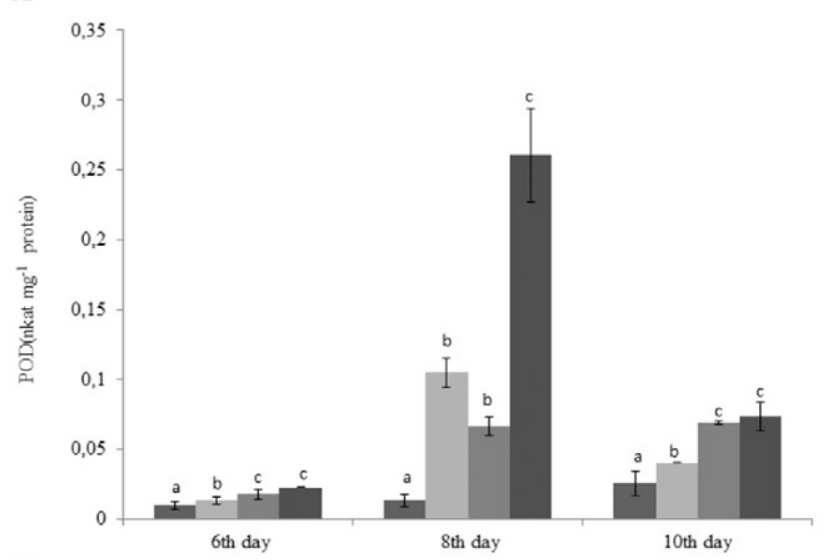

C

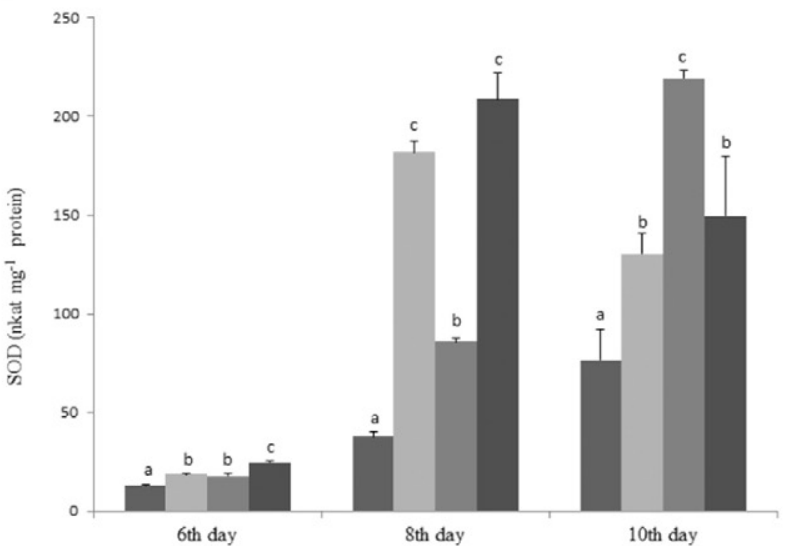

E

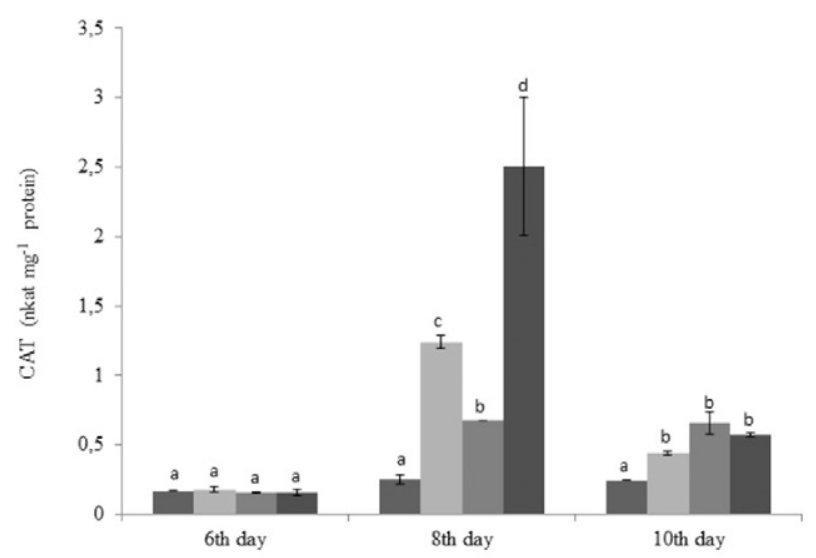

G

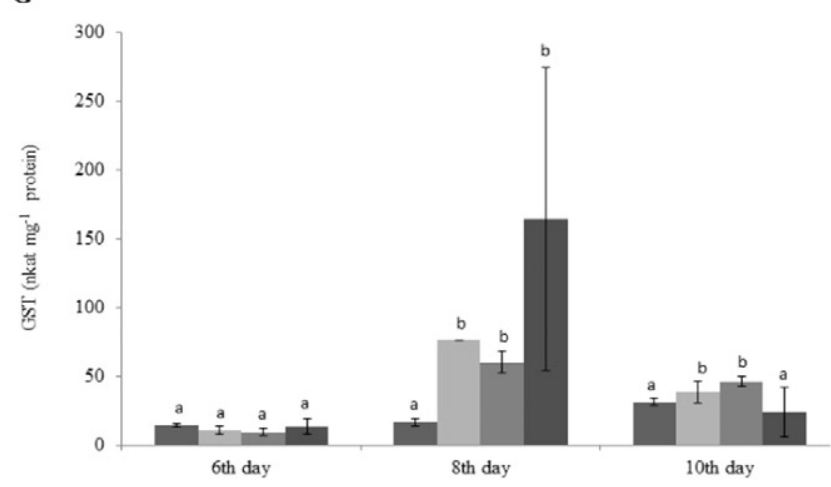

B

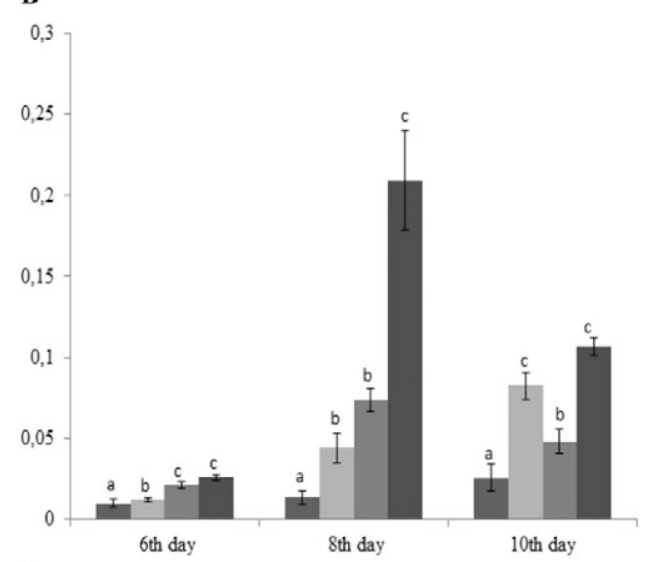

D

- Control

$=25 \mathrm{mg} / \mathrm{L}$

$=50 \mathrm{mg} / \mathrm{L}$

- $100 \mathrm{mg} / \mathrm{L}$

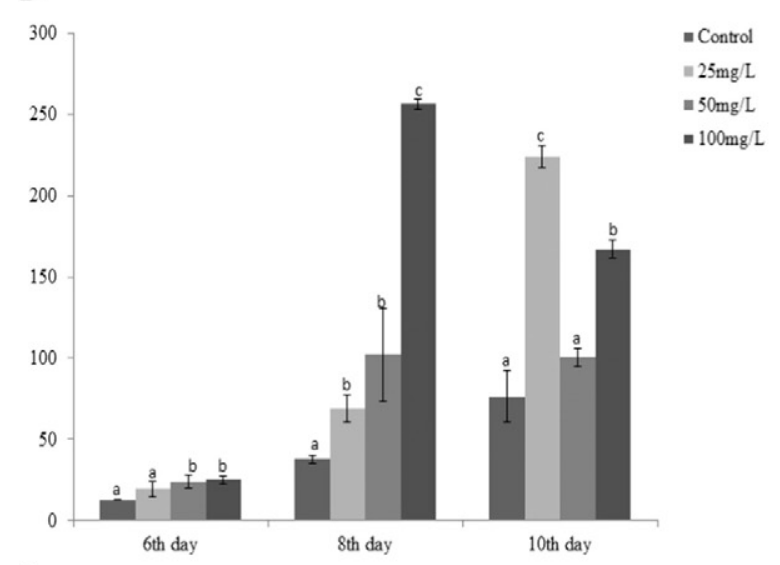

F

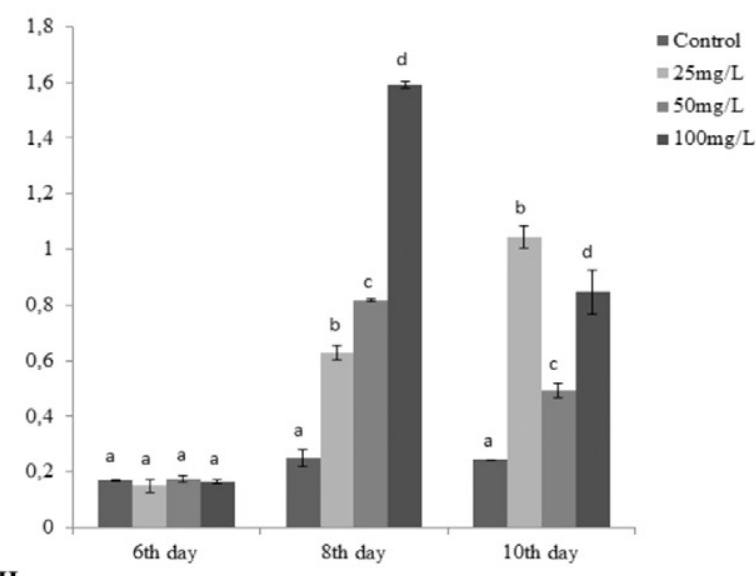

H

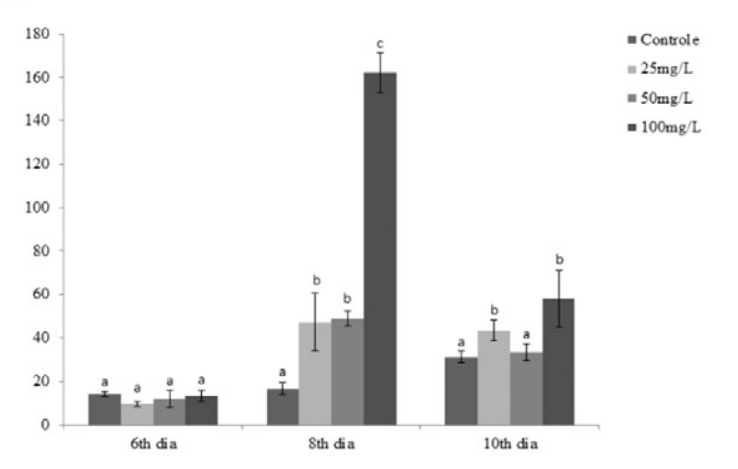

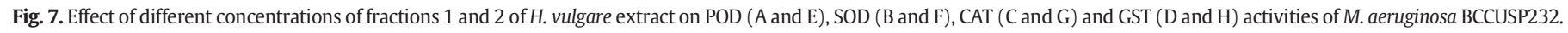

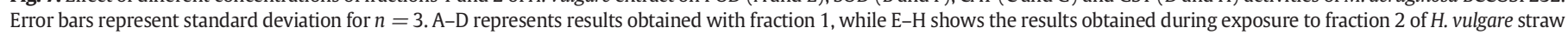
extract. Means with different alphabets are significantly different $(p<0.05)$. 
A-5301 ASYS microplate reader (ASYS Hitech, Austria). Microcystins analysis per sample was carried out in triplicates. The ELISA method is one of the most common methods employed for cyanotoxins detection and quantification in field and laboratory studies, giving results that significantly correlate $\left(R=0.96 ; p<1.10^{-10}\right)$ with those obtained using HPLC-DAD and LC-MS (see Metcalf et al., 2000; Babica et al., 2006; Bláhová et al., 2009). The Beacon ELISA kit had sensitivity of $0.10 \mu \mathrm{g} \mathrm{L}{ }^{-1}$ MC-LR and cross-reactivity of $100 \%$ for MC-LR and $87 \%$ for MC-RR.

\subsection{Statistical analysis}

The cell density data was subjected to normality (Shapiro-Wilks) and homogeneity of variance (Levene) tests. Significant differences between the mean cell density data obtained from the different treatments were determined using one way analysis of variance (ANOVA). The Tukey's hsd post hoc test was used to separate significantly different means. Where the data was not normal and the variances not homogenous, the Kruskal-Wallis and Dunn tests were employed. All statistical analyses were carried out at $5 \%$ significance level.

\section{Results}

\subsection{Phytochemical screening}

The $H$. vulgare crude extract had $7.5 \mu$ g gallic acid equivalent/mg of extract for total phenols and $30 \mu \mathrm{g}$ rutin equivalent/mg of extract for total flavonoids. The crude extract of $H$. vulgare and fraction 2 had similar HPLC profiles, and indicated that the fractionation technique was ineffective because both samples were primarily comprised of phenolic acids (Fig. 1A, B and C). However, PAD detector scan (200-600 nm) results gave peaks that are typical of phenolic acids absorption bands in the extract, demonstrating that the extraction method used was efficient for obtaining the lignin degradation products of interest (Fig. 2).

\subsection{Oxidative degradation of albumin by barley extract}

Compared to the negative and positive controls, the oxidative activity of the crude extract increased significantly at 500 and $250 \mu \mathrm{g} \mathrm{mL}-1$ crude extract (Fig. 3). Furthermore, a clear increasing extract concentration dependent oxidative degradation of BSA can be observed.

3.3. Bioassay results of Microcystis aeruginosa BCCUSP232 exposed to H. vulgare extract and fractions

The bioassay results of $M$. aeruginosa exposed to $H$. vulgare extract and its fractions are given in Tables 1,2 and 3. Throughout the experiment, $H$. vulgare extract significantly reduced the cell density of the cyanobacterium in a concentration dependent manner. There was complete growth inhibition at the highest extract concentration (500 $\mathrm{mg} \mathrm{L}^{-1}$ ), leading to $100 \%$ mortality at the end of the study (Table 1).

Among the $H$. vulgare extract fractions, fractions 1 and 2 significantly reduced the cell density of the cyanobacterium at 25 and $50 \mathrm{mg} \mathrm{L}^{-1}$. Compared to the crude extract, the inhibitory effect of the fractions was lower (Tables 2 and 3).

Results are means \pm standard deviation for $n=3$. Means with different alphabets per column are significantly different $(p<0.05)$.

Results are means \pm standard deviation for $n=3$. Means with different alphabets per column are significantly different $(p<0.05)$.

\subsection{Internal hydrogen peroxide $\left(\mathrm{H}_{2} \mathrm{O}_{2}\right)$}

Internal $\mathrm{H}_{2} \mathrm{O}_{2}$ concentration of $M$. aeruginosa increased after exposure to the crude extract in a concentration dependent manner (Fig. 4A). From day 8 to 10 , the highest internal $\mathrm{H}_{2} \mathrm{O}_{2}$ concentration was recorded at $500 \mathrm{mg} \mathrm{L}^{-1}$ crude extract. For fraction 1, only the $100 \mathrm{mg} \mathrm{L}^{-1}$ treatment significantly increased $\mathrm{H}_{2} \mathrm{O}_{2}$ concentration on days 6 and 8 , while on day 10, there were no significant differences between the treatments and control (Fig. 4B). On the other hand, $M$. aeruginosa exposed to fraction 2 had a slight increase in $\mathrm{H}_{2} \mathrm{O}_{2}$ concentration at $25 \mathrm{mg} \mathrm{L}^{-1}$ on day 6 , and significantly lowered levels at 50 and $100 \mathrm{mg} \mathrm{L}^{-1}$ on day 8 (Fig. 4C).

\subsection{Lipid peroxidation}

The lipid peroxidation results of $M$. aeruginosa exposed to $H$. vulgare crude extract, and fractions 1 and 2 are given in Fig.5. Exposure to the crude extract significantly increased lipid peroxidation on day 6 , while
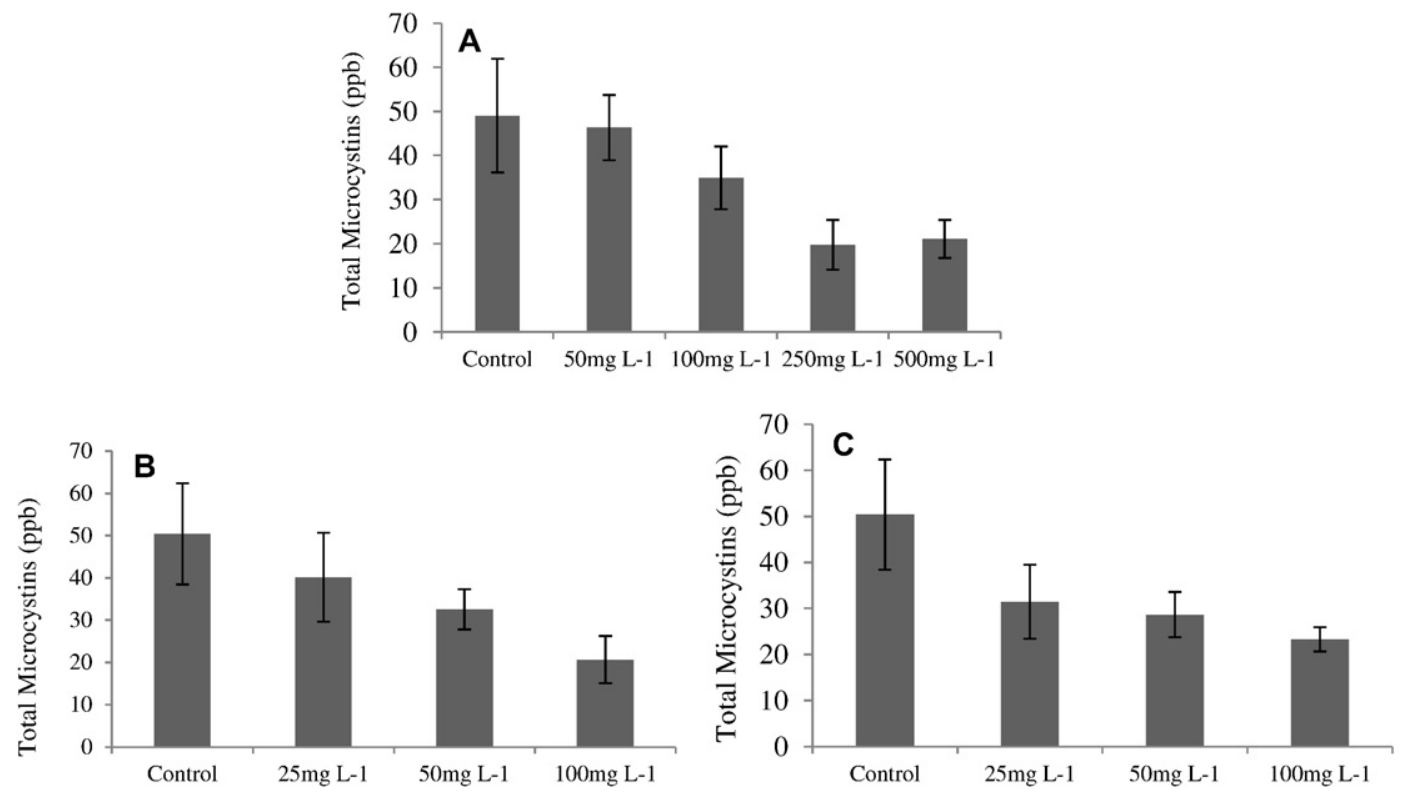

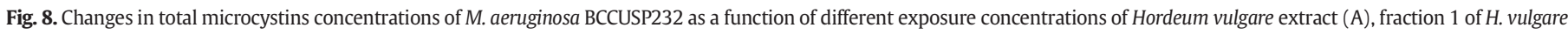
extract (B), and fraction 2 of H. vulgare extract (C). Error bars represent standard deviation for $n=3$. 
on day 8 only the $50 \mathrm{mg} \mathrm{L}^{-1}$ treatment significantly increased it (Fig. 5A). The most significant increase in lipid peroxidation of the cyanobacterium after exposure to fractions 1 and 2 occurred on day 10 at $100 \mathrm{mg} \mathrm{L}^{-1}$ treatment (Fig.5B and C).

\subsection{Antioxidant enzyme activities}

POD activity significantly increased at 250 and $500 \mathrm{mg} \mathrm{L}^{-1}$ crude extract on day 6 , and on day 8 , all crude extract concentrations resulted in significantly higher POD activity than the control (Fig. 6 A). On day 10, only the $100 \mathrm{mg} \mathrm{L}^{-1}$ crude extract concentration caused a significant increase in POD activity of $M$. aeruginosa. There was a general significant $(p<0.05)$ increase in SOD activity in the presence of the crude extracts from day 6 to 8 of the experiment (Fig. $6 \mathrm{~B}$ ). However, at $500 \mathrm{mg} \mathrm{L}^{-1}$ crude extract, SOD activity was significantly inhibited on days 8 and 10 of the assay. The most significant changes in GST activity were recorded on days 8 and 10 of the experiment. Specifically, GST activity increased at 50 and $100 \mathrm{mg} \mathrm{L}^{-1}$ crude extract on day 8 , while at $500 \mathrm{mg} \mathrm{L}^{-1}$ crude extract it was inhibited on day 10.

All concentrations of both fractions significantly increased POD and SOD activities of the cyanobacterium from day 6 to 10 of the assay (Fig. 7A, B, E and F). Furthermore, the most significant fraction concentration dependent changes in POD, SOD and CAT activities were recorded on days 8 and 10 of the assay (Fig. 7A, B, C, E, F and G). On day 6 of the assay, the change in GST activity was not significant between the different concentrations of the fractions ( 1 and 2 ) and the control (Fig. 7D and $\mathrm{H})$. However, from day 8 to 10 of the assay, the different concentrations of fractions 1 and 2 significantly increased the GST activity of $M$. aeruginosa. Furthermore, the highest GST activity was recorded at $100 \mathrm{mg} \mathrm{L}^{-1}$ of fractions 1 and 2 on days 8 and 10 of the assay.

\subsection{Total microcystins}

Increasing concentrations of the crude extract, fraction 1 and fraction 2 lowered total microcystins concentrations in a concentration dependent manner on day 10 of the experiment (Fig. 8A, B and C). The most significant decline in total microcystins was observed at 250 to $500 \mathrm{mg} \mathrm{L}^{-1}$ of the crude extract, and $100 \mathrm{mg} \mathrm{L}^{-1}$ of fractions 1 and 2.

\section{Discussion}

Initial analysis of the extract revealed the presence of phenolic acids, which is in agreement with the findings of Merken and Beecher (2000), and Sticher (2008). Furthermore, Pillinger et al. (1992), Everall and Lees (1997), and Martin and Ridge (1999) demonstrated that the degradation products of barley straw such as polyphenolic compounds (e.g. cinnamic acid, p-coumaric acid, sinapic acid, ferulic acid, caffeic acid) and quinones inhibited the growth of algae and cyanobacteria. This means that the extraction method was efficient for obtaining the lignin degradation products of interest (Fig. 2).

As a means of understanding the mechanism of action of barley straw extract and its fractions, physiological and biochemical changes of $M$. aeruginosa were investigated. This is because most studies on the effect of barley straw extracts have been restricted to its growth inhibitory effects (Martin and Ridge, 1999; Waybright et al., 2009; Iredale et al., 2012), while the mechanisms of action have rarely been given consideration. An assessment of the pro-oxidative activity of the extract demonstrated that increasing extract concentration increased the oxidative damage caused by barley straw. The increase in pro-oxidative activity of the extract correlated with increased presence of polyphenols. Aguiar et al. (2007) demonstrated that polyphenolic compounds are potent pro-oxidative agents; and their activity is directed at reducing $\mathrm{Fe}^{+3}$ and $\mathrm{Cu}^{+2}$, and promoting reactive oxygen species (ROS) production primarily in the form of $\mathrm{OH}$ from Fenton and Fenton cuprous reactions. According to Torres et al. (2008) and Chia et al. (2015a, 2015b), exposure to toxic agents and/or stressful conditions directly interferes with the production and concentration of ROS in algae, by significantly increasing their levels, and consequently, destroying intracellular components. In addition, Grant and Loake (2000) reported that increased ROS content in the tissues of target organisms leads to their death.

Based on the pro-oxidative activities recorded, changes in intracellular $\mathrm{H}_{2} \mathrm{O}_{2}$ of $M$. aeruginosa during exposure to $\mathrm{H}$. vulgare extract and fractions were investigated. This revealed a significant increase in $\mathrm{H}_{2} \mathrm{O}_{2}$ formation after exposure to the extract and fractions of $H$. vulgare, which is in agreement with the findings of Dummermuth et al. (2003), Pinto et al. (2003) and Halliwell (2007). The authors showed that the induction of oxidative stress may accelerate oxidative damage, leading to substantial changes in the conformation of important biomolecules such as membrane lipids, proteins and nucleic acids. In addition, Torres et al. (2008) and Mikula et al. (2012) demonstrated that oxidative stress damages photosynthetic structures, reduces pigment levels and photosynthetic potential, and inhibits biomass production, which explains the decline in cell density of M. aeruginosa during exposure to $H$. vulgare extract and fractions in the present study.

In order to determine the extent of oxidative damage caused by increased ROS production in M. aeruginosa during exposure to $H$. vulgare extract and fractions, MDA levels were measured. The observed increased production of MDA with increasing $H$. vulgare extract and fraction concentrations was a clear indication of membrane destabilization by lipid peroxidation. Lipid peroxidation is commonly caused by increased ROS production (Meng et al., 2015), which generates an imbalance in the cellular redox state and is accompanied by increased MDA content (Bhandari and Sharma, 2006). Similar to our results, several researchers have observed increased lipid peroxidation in photosynthesizing organisms exposed to different bioactive compounds (He and Häder, 2002; Yu et al., 2003; Mishra et al., 2008; Li et al., 2016).

The determination of antioxidant enzyme activities was also used to evaluate the mechanisms of action of $H$. vulgare straw extract and fractions on $M$. aeruginosa. These enzymes participate in the elimination and/or reduction of the damage caused by ROS (Zhang et al., 2013; Lozano et al., 2014; Chia et al., 2015b). As a first line of defense, POD and CAT are involved in the sequestration and conversion of $\mathrm{H}_{2} \mathrm{O}_{2}$ to $\mathrm{H}_{2} \mathrm{O}$ and $\mathrm{O}_{2}$ (Qian et al., 2012). This explains the increase in activities of both enzymes recorded during exposure of $M$. aeruginosa to crude extract and fractions of $H$. vulgare straw. These results corroborate with those reported by Chia et al. (2015b). The authors observed an upregulation of POD and CAT activities of M. aeruginosa exposed to different anatoxin-a concentrations. The changes in SOD activity recorded in the present study are indicative of increased production of the $\mathrm{O}_{2}^{-}$ molecule. Superoxide dismutase is responsible for catalyzing the dismutation of $\mathrm{O}_{2}^{-}$to $\mathrm{H}_{2} \mathrm{O}_{2}$ and $\mathrm{O}_{2}$ (Gratão et al., 2005; Halliwell, 2006; Miller, 2012). The inhibition of SOD activities observed in the present study has been linked previously to a rapid substrate overload of the enzyme during oxidative stress (Blokhina et al., 2003). In addition, our results demonstrated that increased ROS content can be characterized by a fall in the efficiency of the enzymes or molecules sequestering these molecules, vis-à-vis the antioxidant defenses, thereby resulting in a breakdown of the balance between the production and removal of ROS (Halliwell and Whiteman, 2004; Scandalios, 2005). The increased GST activity observed during exposure of the cyanobacterium to $H$. vulgare straw extract and fractions is directly related to the role it plays in the biotransformation and detoxification of bioactive substances in different organisms (Ziglari et al., 2008; Vestena et al., 2011; Yamuna et al., 2012). The enzyme catalyzes the conjugation of bioactive secondary metabolites with the reduced form of glutathione (GSH), leading to the transformation, and finally, detoxification of the molecules (Salinas and Wong, 1999; Vestena et al., 2011).

The environmental and human health effects of microcystins require that algicidal investigations consider changes in the levels of these toxins. In the present study, crude extract and fraction treatments had a dose dependent reduction effect on total microcystins content of 
M. aeruginosa. A number of studies have shown that bioactive substances such as cylindrospermopsin (Rzymski et al., 2014) and anatoxin-a (Chia et al., 2015a) inhibit the ability of M. aeruginosa to produce microcystins, which is in agreement with our results. While the physiological functions of microcystins are still debated, the molecules act as allelopathic agents in intra- and inter-specific interactions, and enhance colony formation and maintenance by cyanobacteria (Pimentel and Giani, 2014). According to Dziallas and Grossart (2011), microcystins play important protective roles against oxidative stress. Therefore, the ability of $H$. vulgare extract and fractions to inhibit the production of microcystins enhances its algicidal potential.

\section{Conclusion}

The results obtained in the present study confirm that $H$. vulgare (barley) straw extract and fractions are capable of controlling $M$. aeruginosa growth. As a contribution to understanding the mechanism of action of $H$. vulgare degradation extract and its fractions on the cyanobacterium, our study revealed a decline in total microcystin concentrations, while internal $\mathrm{H}_{2} \mathrm{O}_{2}$ content and lipid peroxidation were increased. In addition, the activities of important antioxidant enzymes were significantly altered.

\section{Acknowledgments}

This work was supported by the Sao Paulo Research Foundation (FAPESP grant number: 2014/17126-0).

\section{References}

Aguiar, A., Ferraz, A., Contreras, D., Rodríguez, J., 2007. Mecanismo e aplicações da reação de fentonassistida por compostos fenólicos redutores de ferro. Quim Nova 30 (3), 623-628.

Babica, P., Kohoutek, J., Bláha, L., Adamovsky, O., Marsálek, B., 2006. Evaluation of extraction approaches linked to ELISA and HPLC for analyses of microcystin-LR, -RR and -YR in freshwater sediments with different organic material contents. Anal. Bioanal. Chem. 85, 1545-1551.

Barrett, P.R.F., Curnow, J.C., Littlejohn, J.W., 1996. The control of diatom and cyanobacterial blooms in reservoirs using barley straw. Hydrobiologia 340, 307-311.

Bártová, K., Hilscherová, K., Babica, P., Maršálek, B., 2011. Extract of Microcystis water bloom affects cellular differentiation in filamentous cyanobacterium Trichormus variabilis (Nostocales, Cyanobacteria). J. Appl. Phycol. 23, 967-973.

Bhandari, R., Sharma, P.K., 2006. Effect of UV-B on photosynthesis, membrane lipids and MAAs in marine cyanobacterium, Phormidium corium (Agardh) Gomont. Indian J. Exp. Biol. 44 (4), 330-335.

Bittencourt-Oliveira, M.C., Oliveira, M.C., Pinto, E., 2011. Diversity of microcystinproducing genotypes in Brazilian strains of Microcystis (Cyanobacteria). Braz. J. Biol. 71 (1), 209-216.

Bláhová, L., Oravec, M., Marsálek, B., Sejnohová, L., Simek, Z., Bláha, L., 2009. The first occurrence of the cyanobacterial alkaloi toxin cylindrospermopsin in the Czech Republic as determined by immunochemical and LC/MS methods. Toxicon 53, 519-524.

Blokhina, O., Virolainen, E., Fagerstedt, K.V., 2003. Antioxidants, oxidative damage and oxygen deprivation stress: a review. Ann. Bot. 91, 179-194.

Bradford, M., 1976. A rapid and sensitive method for the quantitation of microgram quantities of protein utilizing the principle of protein-dye binding. Anal. Biochem. 72, 243-254.

Chen, J., Xie, P., Zhang, D.W., Lei, H.H., 2007. In situ studies on the distribution patterns and dynamics of microcystins in a biomanipulation fish - bighead carp (Aristichthys nobilis). Environ. Pollut. 147 (1), 150-157.

Chia, A.M., Cordeiro-Araújo, M.K., Bittencourt-Oliveira, M.C., 2015a. Growth and antioxidant response of Microcystis aeruginosa (Cyanobacteria) exposed to anatoxin-a. Harmful Algae 49, 135-146.

Chia, A.M., Chimdirim, P.K., Japhet, W.S., 2015b. Lead induced antioxidant response and phenotypic plasticity of Scenedesmus quadricauda(Turp.) de Brebisson under different nitrogen conditions. J. Appl. Phycologia 27 (1), 293-302

Chorus, I., Bartram, J. (Eds.), 1999. Toxic Cyanobacteria in Water: a Guide to the Public Health Consequences, Monitoring and Management. E \& FNSpon, London (pp. 416).

Demiral, T., Türkan, I., 2005. Comparative lipid peroxidation, antioxidant defense systems and proline content in roots of two rice cultivars differing in salt tolerance. Environ. Exp. Bot. 53, 247-257.

Drabkova, M., Matthijs, H.C.P., Admiraal, W., Marslek, B., 2007. Selective effects of $\mathrm{H}_{2} \mathrm{O}_{2}$ on cyanobacterial photosynthesis. Photosynthetica 45 (3), 363-369.

Dummermuth, A.L., Karsten, U., Fisch, K.M., Konig, G.M., Wiencke, C., 2003. Responses of marine macroalgae to hydrogen-peroxide stress. J. Exp. Mar. Biol. Ecol. 289, 103-121.

Dziallas, C., Grossart, H.P., 2011. Increasing oxygen radicals and water temperature select for toxic Microcystis sp. PLoS One 6, e25569. http://dx.doi.org/10.1371/journal.pone. 0025569.
El-Shehawy, R., Gorokhova, E., Fernández-Pinãs, F., Del Campo, F.F., 2012. Global warming and hepatotoxin production by cyanobacteria: what can we learn from experiments? Water Res. 46, 1420-1429.

Everall, N.C., Lees, D.R., 1997. The identification and significance of chemicals released from decomposing barley straw during reservoir algal control. Water Res. 31, 614-620.

Ferrier, M.D., Butler, B.R., Terlizzi, D.E., Lacouture, R.V., 2005. The effects of barley straw (Hordeum vulgare) on the growth of freshwater algae. Bioresour. Technol. 96 1788-1795.

Gangstad, E.O., 1986. Freshwater Vegetation Management. Thomas Publications, Fresno, CA

Gibson, M.T., Welch, I.M., Barrett, P.R.F., Ridge, I., 1990. Barley straw as an inhibitor of algal growth. 2. Laboratory studies. J. Appl. Phycol. 2, 241-248.

Gorham, P.R., Mclachlon, J.R., Hammer, V.T., Kim, W.K., 1964. Isolation and culture of toxic strains of Anabaena flos-aquae (Lyngb.). Breb. Verh. Int. Ver. Theor. Angew. Limnol. Verh 15, 796-804.

Grant, J.J., Loake, G.J., 2000. Role of reactive oxygen intermediates and cognate redox signaling in disease resistance. Plant Physiol. 124, 21-29.

Gratão, P.L., Polle, A., Lea, P.J., Azevedo, R.A., 2005. Making the life of heavy metal-stressed plants a little easier. Funct. Plant Biol. 32, 481-494.

Gugger, M., Lenoir, S., Berger, C., Ledreux, A., Druart, J.C., Humbert, J.F., Guette, C., Bernard, C., 2005. First report in a river in France of the benthic cyanobacterium Phormidium favosum producing anatoxin-a associated with dog neurotoxicosis. Toxicon 45 (7) 919-928.

Hajimahmoodi, M., Faramarzi, M.A., Mohammadi, N., Soltani, N., Oveisi, M.R, NafissiVarcheh, N., 2010. Evaluation of antioxidant properties and total phenolic contents of some strains of microalgae. J. Appl. Phycol. 22, 43-50.

Halliwell, B., 2006. Reactive species and antioxidants. Redox biology is a fundamental theme of aerobic life. Plant Physiol. 14, 312-322.

Halliwell, B., 2007. Biochemistry of oxidative stress. Biochem. Soc. Trans. 35, 1147-1150.

Halliwell, H., Whiteman, M., 2004. Measuring reactive species and oxidative damage in vivo and in cell culture: how should you do it and what do the results mean. $\mathrm{Br}$. J. Pharmacol. 142, 231-255.

He, Y.Y., Häder, D.P., 2002. Reactive oxygen species and UV-B: effect on cyanobacteria. Photochem. Photobiol. Sci. 1, 729-736.

Heisler, J., Glibert, P., Burkholder, J., Anderson, D., Cochlan, W., Dennison, W., 2008. Eutrophication and harmful algal blooms: a scientific consensus. Harmful Algae 8, 3-13.

Hsieh, C.L., Lin, Y.C., Ko, W.S., Peng, C.H., Huang, C.N., Peng, R.Y., 2005. Inhibitory effect of some selected nutraceutic herbs on LDL glycation induced by glucose and glyoxal. J. Ethnopharmacol. 102, 357-363.

Hunt, J.V., Simpson, J.A., Dean, R.T., 1988. Hydroperoxide-mediated fragmentation of proteins. Biochem. J. 250 (1), 87-93.

Iredale, R.S., McDonald, A.T., Adams, D.G., 2012. A series of experiments aimed at clarifying the mode of action of barley straw in cyanobacterial growth control. Water Res. 46, 6095-6103.

Jana, S., Choudhuri, M.A., 1982. Glycolate metabolism of three submerged aquatic angiosperms during aging. Aquat. Bot. 12, 345-354.

Johansson, L.H., Borg, L.A.H., 1988. A spectrophotometric method for determination of catalase activity in small tissue samples. Anal. Biochem. 174, 331-336.

Kocha, T., Yamaguchi, M., Ohtaki, H., Fukuda, T., Aoyagi, T., 1997. Hydrogen peroxidemediated degradation of protein: different oxidation modes of copper- and irondependent hydroxyl radicals on the degradation of albumin. Biochim. Biophys. Acta 1337, 319-326.

Kotopoulis, S., Schommartz, A., Postema, M., 2009. Sonic cracking of blue-green algae. Appl. Acoust. 70, 1306-1312.

Laemmli, U.K., 1970. Cleavage of structural proteins during the assembly of the head of bacteriophage T4. Nature 227, 680-685.

Leflaive, J., Ten-Hage, L., 2007. Algal and cyanobacterial secondary metabolites in freshwaters: a comparison of allelopathic compounds and toxins. Freshw. Biol. $52,199-214$.

Li, J., Liu, Y., Zhang, P. Zeng G, Cai, X, Liu, S, Yin, Y, Hu, X, Hu, X, Tan, X, 2016. Growth inhibition and oxidative damage of Microcystis aeruginosa induced by crude extract of Sagittaria trifolia tubers. J. Environ. Sci. 43, 40-47.

Liang, H., Nan, J., 2009. Algae removal by ultrasonic irradiation-coagulation. Desalination 239, 191-197.

Lozano, P., Trombini, C., Crespo, E., Blasco, J., Moreno-Garrido, I., 2014. ROI-scavenging enzyme activities as toxicity biomarkers in three species of marine microalgae exposed to model contaminants (copper, Irgarol and atrazine). Ecotoxicol. Environ. Saf. 104 294-301.

Madhava Rao, K.V., Sresty, T.V.S., 2000. Antioxidative parameters in the seedlings of pigeonpea (Cajanus cajan (L.) Millspaugh) in response to $\mathrm{Zn}$ and Ni stresses. Plant Sci. 157, 113-128

Martin, D., Ridge, I., 1999. The relative sensitivity of algae to decomposing barley straw. J. Appl. Phycol. 11, 285-291.

Mauch, F., Dudler, R., 1993. Differential induction of distinct glutathione-S-transferase of wheat by xenobiotics and by pathogen attack. Plant Physiol. 102, 1193-1201.

Meng, P., Pei, H., Hu, W., Liu, Z., Li, X., Xu, H., 2015. Allelopathic effects of Ailanthus altissima extracts on Microcystis aeruginosa growth, physiological changes and microcystins release. Chemosphere 141, 219-226.

Merken, H.M., Beecher, G.R., 2000. Measurement of food flavonoids by highperformanceliquid chromatography: a review. J. Agric. Food Chem. 28, 577-599.

Metcalf, J.S., Bell, S.G., Codd, G.A., 2000. Production of novel polyclonal antibodies against the cyanobacterial toxin microcystin-LR and their application for the detection and quantification of microcystins and nodularin. Water Res. 34, 2761-2769.

Mikula, P., Zezulka, S., Jancula, D., Marsalek, B., 2012. Metabolic activity and membrane integrity changes in Microcystis aeruginosa - new findings on hydrogen peroxide toxicity in cyanobacteria. Eur. J. Phycol. 47, 195-206.

Miller, A.F., 2012. Superoxide dismutases: ancient enzymes and new insights. FEBS Lett. 586 (5), 585-595.

Mishra, Y., Bhargava, P., Thapar, R., Srivastava, A., Rai, L.C., 2008. A comparative study of antioxidative defense system in the copper and temperature acclimated strains of Anabaena doliolum. World J. Microbiol. Biotechnol. 24, 2997-3004. 
Misra, H.P., Fridovich, I., 1972. The generation of superoxide radical antioxidation of haemoglobin. J. Biol. Chem. 247, 6960-6962.

Ó Huallacháin, D., Fenton, O., 2008. Artificial lake amelioration: implications for submerged aquatic vegetation. Proceedings of Environ. Dundalk, Rep. of Ireland (p 92).

Ó Huallacháin, D., Fenton, O., 2010. Barley (Hordeum vulgare)-induced growth inhibition of algae: a review. J. Appl. Phycol. 22, 651-658.

Park, M.H., Han, M.S., Ahn, C.Y., Kim, H.S., Yoon, B.D., Oh, H.M., 2006. Growth inhibition of bloom-forming cyanobacterium Microcystis aeruginosa by rice straw extract. Lett. Appl. Microbiol. 43, 307-312.

Pearson, L., Mihali, T., Moffitt, M., Kellmann, R., Neilan, B., 2010. On the chemistry, toxicology and genetics of the cyanobacterial toxins, microcystin, nodularin, saxitoxin and cylindrospermopsin. Mar. Drugs 8, 1650-1680.

Pillinger, J.M., Cooper, J.A., Ridge, I., Barrett, P.R.F., 1992. Barley straw as an inhibitor of algal growth III; the role of fungal decomposition. J. Appl. Phycol. 4, 353-355.

Pimentel, J.S., Giani, A., 2014. Microcystin production and regulation under nutrient stress conditions in toxic microcystis strains. Appl. Environ. Microbiol. 80 (18), 5836-5843.

Pinto, E., Sigaud-Kutner, T.C.S., Leitao, M.A., Okamoto, O.K., Morse, D., Colepicolo, P., 2003. Heavy metal induced oxidative stress in algae. J. Phycol. 39, 1008-1018.

Qian, H., Pan, X., Chen, J., Zhou, D., Chen, Z., Zhang, L. Fu, Z., 2012. Analyses of gene expression and physiological changes in Microcystis aeruginosa reveal the phytotoxicities of three environmental pollutants. Ecotoxicology 21, 847-859.

Rajabi, H., Filizadeh, Y., Soltani, M., Fotokian, M.H., 2010. The use of barley straw for controlling of cyanobacteria under field application. J. Fish. Aquat. Sci. 5, 394-401.

Reddy, J.K., Suga, T., Mannaerts, G.P., Lazarow, P.B., Subramani, S., 1995. Peroxisomes: biology and role in toxicology and disease. Ann. N. Y. Acad. Sci.

Rodriguez, E., Onstad, G.D., Kull, T.P., Metcalf, J.S., Acero, J.L., Von Gunten, U., 2007. Oxidative elimination of cyanotoxins: comparison of ozone, chlorine, chlorine dioxide and permanganate. Water Res. 41 (15), 3381-3393.

Rzymski, P., Poniedzialek, B., Kokocinski, M., Jurczk, T., Lipski, D., Wiktorowicz, K., 2014. Interspecific allelopathy in cyanobacteria: cylindrospermopsin and Cylindrospermopsis raciborskii effect on the growth and metabolism of Microcystis aeruginosa. Harmful Algae 35, 1-8.

Salinas, A.E., Wong, M.G., 1999. Glutathione S-transferases - a review. Curr. Med. Chem. 6 , 279-309.

Scandalios, J.V., 2005. Oxidative stress: molecular perception and transduction of signals triggering antioxidant gene defenses. Braz. J. Med. Biol. Res. 38 (7), 995-1014.

Sivonen, K., Jones, G., 1999. Cyanobacterial toxins. In: Chorus, I., Bartram, J. (Eds.), Toxic Cyanobacteria in Water: a Guide to their Public Health Consequences, Monitoring and Management. E and FN Spon, London, pp. 41-111.
Smith, G.D., Doan, N.T., 1999. Cyanobacterial metabolites with bioactivity against photosynthesis in cyanobacteria, algae and higher plants. J. Appl. Phycol. 11, 337-344.

Stagos, D., Portesis, N., Spanou, C., Mossialos, D., Aligiannis, N., Chaita, E., Panagoulis, C., Reri, E., Skaltsounis, L., Tsatsakis, A.M., Kouretas, D., 2012. Correlation of total polyphenolic content with antioxidant and antibacterial activity of 24 extracts from Greek domestic Lamiaceae species. Food Chem. Toxicol. 50, 4115-4124.

Sticher, O., 2008. Natural product isolation. Nat. Prod. Rep. 25, 517-554.

Torres, M.A., Barros, M.P., Campos, S.C.G., Pinto, E., Rajamani, S., Sayre, R.T., Colepicolo, P., 2008. Biochemical markers in algae and marine pollution: a review. Ecotoxicol. Environ. Saf. 71 (1), 1-15.

Vestena, S., Cambraia, J., Ribeiro, C., Oliveira, J.A., Oliva, M.A., 2011. Cadmium-induced oxidative stress and antioxidant enzyme responsein water hyacinth and Salvinia. Braz. J. Plant Physiol. 23, 131-139.

Vymazal, J., 1995. Algae and Element Cycling in Wetlands. Lewis Publishers, Boca Raton, FL.

Waybright, T. Terlizzi, DE Ferrier, M.D 2009. Chemical characterization of the aqueous algistatic fraction of barley straw (Hordeum vulgare) inhibiting Microcystis aeruginosa. J. Appl. Phycol. 21 (3), 333-340.

WHO, 2004. Guidelines for Drinking Water Quality. third ed. Vol. 1 (Geneva).

Yamuna, A., Saravana Bhavan, P., Geraldine, P., 2012. Glutathione S-transferase and metallothionein levels in the freshwater prawn Macrobrachium malcolmsonii ex-posed to mercury. J. Environ. Biol. 33, 133-137.

Yao, X., Zhu, L., Chen, Y., Tian, J., Wang, Y., 2013. In vivo and in vitro antioxidant activity and $\alpha$-glucosidase, $\alpha$-amylase inhibitory effects of flavonoids from Cichorium glandulosum seeds. Food Chem. 139, 59-66.

Yu, J.Q., Ye, S.F., Zhang, M.F., Hu, W.H., 2003. Effects of root exudates and aqueous rootextracts of cucumber (Cucumis sativus) and allelochemicals, on photosynthesis and antioxidant enzymes in cucumber. Biochem. Syst. Ecol. 31, 129-139.

Zak, A., Musiewicz, K., Kosakowska, A., 2011. Allelopathic activity of the Baltic cyanobacteria against microalgae. Estuar. Coast. Shelf Sci. 30, 1-7.

Zhang, W., Xiong, B., Chen, L., Lin, K., Cui, X., Bi, H., Guo, M., Wang, W., 2013. Toxicity assessment of Chlorella vulgaris and Chlorella protothecoides following exposure to $\mathrm{Pb}$ (II). Environ. Toxicol. Pharmacol. 36, 51-57.

Ziglari, T., Allameh, A., Razzaghi-Abyaneh, M., Khosravi, A.R., Yadegari, M.H., 2008. Comparison of glutathione S-transferase activity and concentration in aflatox- inproducing and their non-toxigenic counterpart isolates. Mycopathologia 166, 219-226. 